\title{
EFFECT OF TEMPERATURE ON PREDATION BY TASMANIAN LACEWING LARVAE
}

\author{
S.S. ISLAM and R.B. CHAPMAN \\ Soil, Plant and Ecological Sciences Division, P.O. Box 84, Lincoln University, \\ Canterbury \\ Corresponding author: chapman@lincoln.ac.nz
}

\begin{abstract}
A laboratory study investigated the predation and development rates of Tasmanian lacewing larvae (Micromus tasmaniae) under constant and fluctuating temperature regimes. Larval development and consumption of second instar cabbage aphid (Brevicoryne brassicae) increased linearly with constant temperatures between $10-30^{\circ} \mathrm{C}$. Under fluctuating daily temperatures $\left(10-25^{\circ} \mathrm{C}\right)$, development and consumption rates were equivalent to those found at a constant $25^{\circ} \mathrm{C}$. Larvae consumed more aphids during later instars and a maximum consumption rate of approximately 10 aphids per day was recorded. Some aspects of larval behaviour are described.

Keywords: Tasmanian lacewing, cabbage aphid, temperature, predation, development.
\end{abstract}

\section{INTRODUCTION}

Tasmanian lacewing, Micromus tasmaniae Walker (Neuroptera: Hemerobiidae), is a common aphid predator found widely throughout Australia and New Zealand (Wise 1963). In New Zealand, many aspects of its biology and ecology have been studied in the field (Hilson 1964; Leathwick \& Winterbourn 1984). Laboratory studies have also examined this species' tolerance to insecticides (Syrett \& Penman 1980; Rumpf et al. 1997), temperature-development relationships (Syrett \& Penman 1981), and its potential for mass rearing (Simeonidis 1995; Harcourt 1996). Its ability to control aphids on lucerne (Cameron et al. 1983; Leathwick 1989) and a greenhouse capsicum crop (Harcourt 1996) have also been evaluated.

Many factors are known to influence the capacity of predators to consume prey (Jervis $\&$ Kidd 1996). Among these, temperature has a profound influence, as this governs the rate of growth and development and hence prey consumption. There has been no systematic evaluation of the influence of temperature on prey consumption by Tasmanian lacewing larvae. Such information could be useful for predicting the potential of this predator under varying environmental conditions. The specific objective of this study was to determine the predation and development rates of Tasmanian lacewing larvae under five constant and one fluctuating temperature regimes. Some observations on larval predation behaviour were also recorded.

\section{Source of insects}

\section{METHODS}

Tasmanian lacewing eggs were obtained from a colony established by Landcare Research New Zealand Ltd. from individuals collected near Lincoln, Canterbury. The eggs were placed in a controlled temperature cabinet at $20^{\circ} \mathrm{C}, 60 \% \mathrm{RH}$ and a $16: 8 \mathrm{~h}$ light:dark photoperiod for 5 days. Newly emerged larvae were collected and placed in a refrigerator at $5-6^{\circ} \mathrm{C}$ until they were needed for the experiments.

Cabbage aphid, Brevicoryne brasssicae L. (Hemiptera: Aphididae) was used as prey for all experiments. Adult winged aphids were collected from a brassica crop near 
Lincoln and placed on young, potted cabbage plants (cv. Golden Acre) in a controlled temperature room at $20^{\circ} \mathrm{C}, 60 \% \mathrm{RH}$ and a 16:8 h light:dark photoperiod. After 2-3 weeks sufficient second instar cabbage aphid nymphs were available for the experiments. Effect of constant temperature

Lacewing larvae and aphids were held in experimental arenas comprising a $44 \mathrm{~mm}$ diameter plastic container that was $58 \mathrm{~mm}$ in height. In the base of the container, a $15 \mathrm{~mm}$ diameter hole was drilled, through which a glass specimen vial could fit tightly. The top of the glass vial was sealed with a rubber stopper in which a small hole was punched to allow the stem of a seedling cabbage leaf to pass. An aqueous nutrient solution was placed in the glass vial to retain the freshness of the cabbage leaf. To prevent lacewings and aphids escaping from each experimental arena, a lid with a $21 \mathrm{~mm}$ diameter ventilation hole covered with fine gauze was secured tightly.

Ten experimental arenas each with one first instar lacewing larva were allocated to each constant temperature. Previous tests had revealed that no more than 40 early instar cabbage aphids were required to sustain larval growth and development through to pupation. To maintain a more or less constant supply of second instar cabbage aphids for the lacewing larvae, 20 aphids were provided at the start of the experiment and the remainder at various intervals throughout the experiment. The temperatures tested were $10,15,20,25$ and $30^{\circ} \mathrm{C}\left( \pm 1^{\circ} \mathrm{C}\right)$. At all times there was a surplus of prey. The number of aphids consumed and lacewing larval mortality was recorded every $24 \mathrm{~h}$ for the duration of the experiment. For each temperature, the experiment stopped when lacewing larvae were preparing to pupate.

Prey consumption and larval development rates were calculated, and the degree days required to complete development under each temperature was estimated using a lower threshold temperature for development of $5^{\circ} \mathrm{C}$ (Leathwick 1989). Linear regression analysis (Minitab, release 12.23) was used to determine the relationship between mean daily consumption rate and time.

\section{Effect of fluctuating temperature}

A separate experiment was carried out using the same methods described above, except that daily fluctuating temperatures were used. During the $16 \mathrm{~h}$ light period, the maximum temperature was set at $25^{\circ} \mathrm{C}$ while during the $8 \mathrm{~h}$ dark period the minimum temperature was $10^{\circ} \mathrm{C}$. In addition to prey consumption and larval development, observations on larval feeding behaviour during the light and dark phases were made.

\section{Effect of constant temperature}

\section{RESULTS}

Tasmanian lacewing larvae completed their development when feeding on cabbage aphids in approximately 12,8 and 6 days at 15,20 and $25^{\circ} \mathrm{C}$, respectively (Table 1 ). At these temperatures, larval mortality ranged from $15-20 \%$. At $30^{\circ} \mathrm{C}$, no larvae survived beyond three days from the start of the experiment. At $10^{\circ} \mathrm{C}$, larval development was completed in 25 days, however, feeding was intermittent and therefore daily feeding rates are not included in Table 1 . The mean total number $( \pm \mathrm{SE})$ of cabbage aphids consumed during larval development was $25.5 \pm 0.7,28.4 \pm 0.74,31.7 \pm 0.94,35.1 \pm 1.06$, $31.8 \pm 2.08$ at $10,15,20,25$ and $30^{\circ} \mathrm{C}$, respectively.

Mean daily consumption rate was linearly related to time, with more aphids being consumed by later instars than early instars. Regressions for mean daily consumption rate over time at $15,20,25$ and $30^{\circ} \mathrm{C}$ were $\mathrm{y}=0.52+3.72 \mathrm{x}\left(\mathrm{r}^{2}=0.96\right), \mathrm{y}=1.02+0.66 \mathrm{x}$ $\left(r^{2}=0.98\right), y=0.65+1.49 x\left(r^{2}=0.98\right)$ and $y=4.8+2.9 x\left(r^{2}=0.94\right)$, respectively. The estimated development rate per day was $0.04,0.08,0.12,0.17$ at $10,15,20$ and $25^{\circ} \mathrm{C}$ respectively. The estimated number of degree days required for larval development ranged between $120-130$ at 25 and $10^{\circ} \mathrm{C}$ respectively.

\section{Effect of fluctuating temperature}

Under fluctuating temperatures $\left(10-25^{\circ} \mathrm{C}\right)$, larvae completed their development $(20 \%$ mortality) in approximately 6 days and consumed an average total of $36+0.7$ aphids. Mean daily prey consumption increased linearly with time $\left(y=0.873+14.7 x, r^{2}=0.98\right)$, 
TABLE 1: Mean number $( \pm \mathrm{SE})$ of cabbage aphids consumed per day by Tasmanian lacewing larvae at different temperatures.

\begin{tabular}{|c|c|c|c|c|c|c|c|c|c|c|c|c|}
\hline \multicolumn{6}{|c|}{ Temp } & \multicolumn{4}{|c|}{ Day } & \multirow[b]{2}{*}{10} & \multirow[b]{2}{*}{11} & \multirow[b]{2}{*}{12} \\
\hline${ }^{\circ} \mathrm{C}$ & 1 & 2 & 3 & 4 & 5 & 6 & 7 & 8 & 9 & & & \\
\hline 15 & $\begin{array}{l}0.5 \\
(0.03)\end{array}$ & $\begin{array}{l}1.0 \\
(0.04)\end{array}$ & $\begin{array}{l}1.1 \\
(0.05)\end{array}$ & $\begin{array}{l}1.2 \\
(0.05)\end{array}$ & $\begin{array}{l}1.8 \\
(0.06)\end{array}$ & $\begin{array}{l}2.1 \\
(0.08)\end{array}$ & $\begin{array}{l}2.4 \\
(0.07)\end{array}$ & $\begin{array}{l}2.5 \\
(0.08)\end{array}$ & $\begin{array}{l}2.9 \\
(0.05)\end{array}$ & $\begin{array}{l}3.9 \\
(0.08)\end{array}$ & $\begin{array}{l}4.3 \\
(0.09)\end{array}$ & $\begin{array}{l}4.7 \\
(0.06)\end{array}$ \\
\hline 20 & $\begin{array}{l}1.5 \\
(0.08)\end{array}$ & $\begin{array}{l}2.2 \\
(0.09)\end{array}$ & $\begin{array}{l}3.2 \\
(0.09)\end{array}$ & $\begin{array}{l}3.9 \\
(0.12)\end{array}$ & $\begin{array}{l}4.4 \\
(0.15)\end{array}$ & $\begin{array}{l}4.8 \\
(0.12)\end{array}$ & $\begin{array}{l}5.6 \\
(0.14)\end{array}$ & $\begin{array}{l}6.2 \\
(0.15)\end{array}$ & & & & \\
\hline 25 & $\begin{array}{l}2.5 \\
(0.11)\end{array}$ & $\begin{array}{l}3.6 \\
(0.15)\end{array}$ & $\begin{array}{l}4.8 \\
(0.18)\end{array}$ & $\begin{array}{l}6.2 \\
(0.21)\end{array}$ & $\begin{array}{l}8.2 \\
(0.20)\end{array}$ & $\begin{array}{l}9.9 \\
(0.21)\end{array}$ & & & & & & \\
\hline 30 & $\begin{array}{l}8.0 \\
(0.6)\end{array}$ & $\begin{array}{l}10.0 \\
(0.7)\end{array}$ & $\begin{array}{l}13.8 \\
(0.78)\end{array}$ & & & & & & & & & \\
\hline
\end{tabular}

and the estimated development rate per day was 0.16 . To complete larval development, an estimated 90 degree days were required.

Periodic observation of larvae revealed they were least active during the dark cycle at $10^{\circ} \mathrm{C}$ and consumed few or no prey during this period. When they emerged from the dark to the light cycle at $25^{\circ} \mathrm{C}$, they became very active and consumed numerous prey. For example, a third instar larva consumed 3-4 aphids during the first $3 \mathrm{~h}$ of the light cycle and a further 3-5 in the following $13 \mathrm{~h}$.

\section{DISCUSSION}

The usefulness of a predator in the management of pests may relate, in part, to its ability to perform adequately under a range of environmental conditions. In this study, we have shown Tasmanian lacewing larvae consumed more prey and develop faster at higher constant temperature than at lower temperatures. Between $10-25^{\circ} \mathrm{C}, 1.4$-fold more aphids were eaten at the higher temperature and the estimated daily development rate was 4.3 -fold higher. At $30^{\circ} \mathrm{C}$, larval mortality was $30-40 \%$ per day and the mean total number of aphids eaten was lower than that at $25^{\circ} \mathrm{C}$, indicating that temperatures above $25^{\circ} \mathrm{C}$ are likely to be less than optimum for this species. This confirms Leathwick's (1989) conclusion that prolonged exposure to temperatures above $25^{\circ} \mathrm{C}$ is lethal to larvae.

Under each constant temperature, mean daily consumption by larvae increased linearly with time reflecting the higher consumption rate by successive larval instars. Around 10 aphids per day appear to be the maximum consumption capacity for late instar lacewing larvae. This will be influenced by the time required for quelling, killing and eating prey, and the digestive pause following consumption. Although these times were not systematically recorded for all instars throughout this study, observations showed that third instars at $10^{\circ} \mathrm{C}$ took approximately $3 \mathrm{~h}$ to capture and eat an aphid while at $25^{\circ} \mathrm{C}$ it took approximately $20 \mathrm{~min}$. Similarly, the digestive pause was $16-20 \mathrm{~h}$ at $10^{\circ} \mathrm{C}$ and $2.5-3 \mathrm{~h}$ at $25^{\circ} \mathrm{C}$. During the digestive pause, larvae would continue to move around prey but would not attack.

Under a daily fluctuating temperature regime $\left(10-25^{\circ} \mathrm{C}\right)$, mean total consumption and development rate were equivalent to that at a constant $25^{\circ} \mathrm{C}$. However, the estimated degree days required to complete larval development under a fluctuating temperature regime were lower than that at constant temperatures. Such discrepancies are common, and errors in degree day estimation are the likely cause (Jervis \& Kidd 1996). The reliability of the degree day estimates for larval development under constant temperatures can also be questioned in view of the those values derived by Syrett \& Penman (1981) and Leathwick (1989) which were 111 and 100 degree days, respectively. However, prey consumption under constant and fluctuating temperatures was similar and this is 
consistent with the observations that larvae were most active and consumed most prey during the warmer light phase and remained relatively inactive during the cooler dark phase of the cycle. Modelling using degree day estimates might therefore be confined to using temperatures recorded during the light phase.

This study has demonstrated that prey consumption by Tasmanian lacewing larvae is temperate dependent and increases with larval development to a maximum of about 10 aphids per day. Temperatures above $25^{\circ} \mathrm{C}$ are likely to be sub-optimal for this species and rapid mortality occurs at $30^{\circ} \mathrm{C}$. This suggests Tasmanian lacewing larvae might not suitable as a biological control agent for aphids on protected crops where higher temperatures typically occur.

\section{REFERENCES}

Cameron, P.J.; Allan, D.J.; Walker, G.P.; Wightman, J.A. 1983: Management experiments on aphids (Acyrthosiphon spp.) and beneficial insects in lucerne. N.Z. J. Exp. Agric. 11: 343-349.

Harcourt, N.R. 1996: Evaluation of the potential of the Tasmanian brown lacewing, Micromus tasmaniae Walker (Neuroptera: Hemerobiidae) as a biocontrol agent of aphids on glasshouse capsicums. MSc thesis, Lincoln University, New Zealand.

Hilson, R.J.D. 1964: The ecology of Micromus tasmaniae Walker. MSc thesis, University of Canterbury, New Zealand.

Jervis, M.; Kidd, N. 1996: Insect natural enemies: practical approaches to their study and evaluation. Chapman and Hall, London, United Kingdom.491 p.

Leathwick, D.M. 1989: Applied ecology of the Tasmanian lacewing, Micromus tasmaniae Walker. PhD thesis, Lincoln University, New Zealand.

Leathwick, D.M.; Winterbourn, M.J. 1984: Arthropod predation on aphids in a lucerne crop. N.Z. Entomol. 8: 75-80.

Rumpf, S.; Frampton, C.; Chapman, B. 1997: Acute toxicity of insecticides to Micromus tasmaniae (Neuroptera: Hemerobiidae) and Chrysoperla carnea (Neuroptera: Chrysopidae): $\mathrm{LC}_{50}$ and $\mathrm{LC}_{90}$ estimates for various test durations. J. Econ. Entomol. 90: $34-40$.

Simeonidis, A. 1995: Development of a mass rearing technique for the Tasmanian brown lacewing, Micromus tasmaniae Walker. MApplSc thesis, Lincoln University, New Zealand.

Syrett, P.; Penman, D.R. 1980: Studies of insecticide toxicity to lucerne aphids and their predators. N.Z. J. Agric. Res. 23: 575-580.

Syrett, P.; Penman, D.R. 1981: Developmental threshold temperatures for the brown lacewing, Micromus tasmaniae (Neuroptera: Hemerobiidae). N.Z. J. Zool. 8: 281283.

Wise, K.A.J. 1963: A list of Neuroptera of New Zealand. Pacific Insects 5: 53-58. 